\title{
Risk factors for the development of depression in patients with hepatitis $C$ taking interferon- $\alpha$
}

\author{
This article was published in the following Dove Press journal: \\ Neuropsychiatric Disease and Treatment \\ I3 May 201 I \\ Number of times this article has been viewed
}

\author{
Kimberley J Smith' \\ Suzanne Norris ${ }^{2}$ \\ Cliona O'Farrelly ${ }^{3}$ \\ Shane M O'Mara' \\ 'Trinity College Institute of \\ Neuroscience, ${ }^{2}$ Hepatology Centre, \\ St James's Hospital, Dublin, Ireland; \\ ${ }^{3}$ Department of Biochemistry and \\ Immunology, Trinity College Dublin, \\ Dublin, Ireland
}

Correspondence: Kimberley J Smith Trinity College Institute of Neuroscience, Trinity College Dublin, Lloyd Building, Dublin, Ireland

Tel +353 | 89684 । ।

Fax +353 | 8963483

Email kismith@tcd.ie

\begin{abstract}
Interferon- $\alpha$, currently used for the treatment of hepatitis $C$, is associated with a substantially elevated risk of depression. However, not everyone who takes this drug becomes depressed, so it is important to understand what particular factors may make some individuals more 'at risk' of developing depression than others. Currently there is no consensus as to why interferon-induced depression occurs and the range of putative risk factors is wide and diverse. The identification of risk factors prior to treatment may allow identification of patients who will become depressed on interferon, allowing the possibility of improved treatment support and rates of treatment adherence. Here, we consolidate and review the literature on risk factors, and we discuss the potential confounds within the research examined in order to better isolate the risk factors that may be important in the development of depression in these patients and which might help predict patients likely to become depressed on treatment. We suggest that interactions between psychobehavioral, genetic, and biological risk factors are of particular importance in the occurrence of depression in patients with hepatitis $\mathrm{C}$ taking interferon- $\alpha$.
\end{abstract}

Keywords: interferon- $\alpha$, risk factors, depression, hepatitis $\mathrm{C}$

\section{Background}

Hepatitis $\mathrm{C}$ virus (HCV) is a major cause of liver disease and death and affects $\sim 170$ million people worldwide. ${ }^{1}$ Recent epidemiological studies suggest more than $90 \%$ of transmission in developed countries occurs through the sharing of nonsterilized needles and syringes in the intravenous drug-using population, 'unknown' sources, and 'other' sources such as dialysis, hemophilia, sexual transmission, and tattoos or piercing. ${ }^{2-5}$ Rates through blood transfusion are decreasing dramatically in the developed world due to improved screening for viruses in blood donations since the early 1990 s, although progress is somewhat slower in developing countries. ${ }^{2}$ Progression from initial infection to liver cirrhosis and cancer can take $20-30$ years; ${ }^{6,7}$ thus, complications from chronic $\mathrm{HCV}$ infection are, therefore, anticipated to continue to increase, ${ }^{8}$ with rates of cirrhosis doubling, liver-related deaths tripling, and HCV becoming the leading reason for liver transplantation. ${ }^{9}$

There is no vaccine for HCV; thus, the need for effective treatments for this infection is critical. Currently, the main Federal Drug Authority-approved treatment for $\mathrm{HCV}$ is the use of the proinflammatory cytokine interferon- $\alpha$ (IFN- $\alpha$ ), a multifunctional pleiotropic protein with antiproliferative, antiviral, and immunoregulatory functions, ${ }^{10}$ which is usually used in combination with broad-spectrum antiviral ribavirin. Unfortunately, this treatment is only effective in $\sim 40 \%-80 \%$ of patients, with efficacy varying dramatically between genotypes. ${ }^{11,12}$ Treatment is also 
expensive and has a well-documented profile of physical, behavioral, and psychiatric side effects, including flulike symptoms, fatigue, insomnia, depressed mood, and irritability, ${ }^{12-16}$ all of which could impact upon compliance. Depression is a particularly common side effect that may occur in up to $60 \%$ of patients, ${ }^{17,18}$ and in some rare cases, it may be associated with deliberate self-harm or suicide attempts. ${ }^{19,20}$ The neuropsychiatric side effects of IFN- $\alpha$ therapy are among the commonest causes of treatment discontinuation, ${ }^{21,22}$ and risk factors such as baseline psychiatric symptoms and interpersonal problems can predict poor compliance. ${ }^{23}$ Identification of the risk factors that lead to neuropsychiatric side effects and the associated low adherence rates may help identify patients at risk who may then benefit from additional psychological assessment and support.

Current treatment for IFN- $\alpha$-induced depression involves the coadministration of selective serotonin reuptake inhibitors (SSRIs), which have been shown to improve treatment adherence in depressed patients. ${ }^{24}$ However, variations in prescribing practice exist. Some clinicians wait for the depression to occur before prescribing these drugs, meaning up to a month may pass before a reduction in depressive symptoms occurs. ${ }^{25}$ Other clinicians adopt a policy of prophylactically administering SSRIs to reduce the occurrence of depression and depressive symptomology, with dose modification where necessary, ${ }^{26-28}$ but this means a large number of patients who do not need an SSRI could be prescribed one. Where studies have identified 'at-risk' patients for prophylaxis of antidepressants and psychological support, these have both proven effective methods of reducing the occurrence of depression. ${ }^{29-31}$

In order to avoid depressive complications and associated treatment compliance risks, identification of risk factors for the subsequent development of depression could assist clinicians in deciding to coprescribe an antidepressant and psychological support at the start of antiviral treatment. Here, we provide an overview of data on HCV patients taking IFN- $\alpha$ in order to assess potential risk factors that affect the development of depression.

The main risk factors identified and investigated in this literature review can be divided into five main categories: biological, demographic, treatment related, genetic, and psychobehavioral. Here, we examine these categories and review evidence that these potential risk factors pose a sufficiently substantive risk of depression that pretreatment support should be considered.

\section{Methods}

A literature search was conducted in PubMed using the keywords 'depression', 'interferon- $\alpha$ ', and 'hepatitis C'. A total of 169 English, full-text, original research articles where rates of depression were assessed in the target population were then screened for their assessment of risk factors of depression. Those articles that used formal statistical analysis to assess possible risk factors were then broken down into five broad categories: biological, demographic, treatment related, genetic, and psychobehavioral. Once these categories were identified, further PubMed searches were conducted including category titles and subtitles as additional keywords. In total, 52 articles were assessed as part of the main review, and results from these articles are presented along with supporting evidence.

\section{Review of risk factors Biological risk factors \\ Biological mechanisms}

Many humans or animals administered with a cytokine develop a behavioral syndrome and set of somatic effects termed 'sickness behavior'; these behaviors result in an alteration of the motivational state of an organism so that it can preferentially respond to infections. ${ }^{32-34}$ In other words, the organism will have depressed functioning of mood, activity, and metabolism so that all of its energy is put into fighting illness. The observation that sickness behavior and depression share common features ${ }^{35}$ (see Table 1) has led many researchers to implicate raised levels of cytokines in the pathology of depression, giving rise to the cytokine theory of depression.

Table I Similarities between MDD and sickness behavior ${ }^{36-39}$

\begin{tabular}{|c|c|c|}
\hline & Depression & Sickness behavior \\
\hline Somatic effects & $\begin{array}{l}\text { Fatigue/loss of energy } \\
\text { Weight loss/weight gain } \\
\text { Appetite loss/appetite } \\
\text { increase } \\
\text { Insomnia/hypersomnia }\end{array}$ & $\begin{array}{l}\text { Fatigue } \\
\text { Weight loss } \\
\text { Anorexia } \\
\text { Sleep disorders } \\
\text { Increased body } \\
\text { temperature }\end{array}$ \\
\hline Behavioral effects & $\begin{array}{l}\text { Depressed mood } \\
\text { Feelings of } \\
\text { worthlessness/guilt } \\
\text { Loss of interest in activities } \\
\text { Anhedonia } \\
\text { Inability to concentrate } \\
\text { Psychomotor agitation/ } \\
\text { retardation } \\
\text { Recurrent thoughts of death }\end{array}$ & $\begin{array}{l}\text { Depressed mood } \\
\text { Behavioral despair } \\
\text { Social withdrawal } \\
\text { Anhedonia } \\
\text { Cognitive } \\
\text { impairment } \\
\text { Suppression motor } \\
\text { behavior }\end{array}$ \\
\hline
\end{tabular}


The cytokine theory of depression suggests biological vulnerability in certain individuals that is linked, in part, to the immune system. ${ }^{33}$ This could be exposed by a compound that stimulates the immune system (such as IFN- $\alpha$ ), and increases in cytokines such as interleukin-6 (IL-6) and IL-10 are positively correlated with depressive symptoms. ${ }^{40,41}$ The enhanced cytokine response seen in depressed patients resonates with data that shows that people who become depressed during treatment are more likely to have a sustained antiviral response. ${ }^{42,43}$

Several potential biological mechanisms for this vulnerability to developing an IFN- $\alpha$-induced depression have been examined. ${ }^{17,38,42,44-47}$ Three main mechanisms that are supported by clinical data are introduced briefly before clinical data assessing their relationship with depression is discussed.

\section{Serotonin}

The neurotransmitter serotonin has long been believed to play a role in depression, ${ }^{48,49}$ however, more recent research has linked the observed decrease in serotonin with a cytokinemediated pathway. ${ }^{50,51}$ When IFN- $\alpha$ is administered, it has been shown that there is an upregulation of the enzyme indoleamine 2,3-dioxygenase (IDO) that metabolizes tryptophan, the precursor to serotonin..$^{34}$ Thus, when IDO is overstimulated, there is potentially a reduction in plasma tryptophan and serotonin in the brain (see Figure 1), ${ }^{42,45,52}$ which may lead to depression. ${ }^{51}$

\section{Serotonin as a risk factor}

Clinical studies in HCV patients have provided mixed results regarding the involvement of serotonin in the IFN- $\alpha$-induced depression; some studies support a correlation between lower tryptophan levels and scores on a depression scale ${ }^{53}$ and others do not find any correlation with tryptophan ${ }^{54}$ or whole blood serotonin. ${ }^{55}$ However, lower tryptophan has been correlated with other behavioral issues associated with depression such as increased irritability and aggression. ${ }^{56}$ Reasons for differences in results could be in part explained by the low number of participants in the studies and also the issue of correlating the centrally driven disorder of depression with peripheral biomarkers. This issue has been addressed by two recent studies conducted by Raison et al..$^{57,58}$ The first study found that when IFN- $\alpha$ was administered peripherally, there was an increase in the amount of kynurenine (KYN) and quinolinic acid (QUIN) centrally, which correlated with Montgomery-Asberg Depression Rating Scale (MADRS)

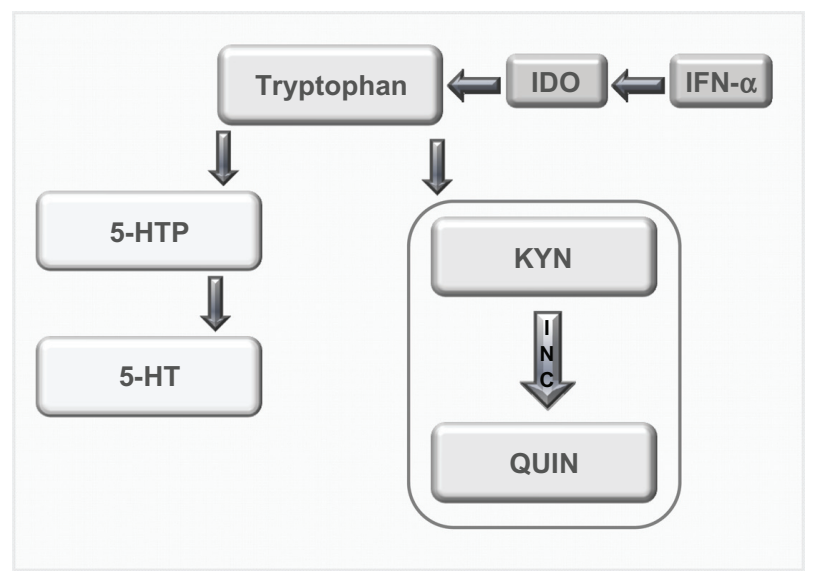

Figure I Tyrptophan-Kynurenine pathway. Diagram showing the alteration of tryptophan metabolism by IFN- $\alpha$. Tryptophan is normally converted in 5-hydroxy tryptophan (5-HTP) and serotonin (5-HT). However, this metabolism is switched to the KYN pathway by IDO, which is induced by immune stimuli such as IFN- $\alpha$, and it is this pathway that produced the neurotoxin quinolinic acid (QUIN). Copyright @ 2002, Elsevier. Adapted with permission from Konsman JP, Parnet P, Dantzer R. Cytokine-induced sickness behaviour: mechanisms and implications. Trends Neurosci. 2002;25(3): I54-159.

scores. The second study found that cerebrospinal fluid (CSF) levels of the serotonin metabolite 5-hydroxyindoleacetic acid were significant predictors of depressive symptoms. ${ }^{57}$

Further support for the involvement of this system is the observation that depressive symptoms in this cohort are effectively ameliorated by the use of SSRIs, ${ }^{25-28,59}$ implicating some role for serotonin in the relief of IFN- $\alpha$-induced depression.

\section{Hypothalamic-pituitary-adrenal axis}

Interferons are acknowledged to activate the hypothalamicpituitary-adrenal (HPA) axis, ${ }^{60}$ which could in part be linked to the development of depression. ${ }^{61-63}$ Recent research has identified a pathway where stress can increase glucocorticoids and corticotrophin-releasing hormones, which act in tandem with an increase in cytokines to disrupt levels of serotonin, norepinephrine, and dopamine..$^{50,64,65}$ Vulnerability in this pathway could mean a stress-related response to cytokines is in part responsible for IFN-induced depression.

\section{HPA axis as a risk factor}

There are mixed results for the involvement of peripheral biomarkers of HPA axis functioning in IFN- $\alpha$-induced depression. One study found that IFN- $\alpha$ does not induce a change in plasma cortisol levels and cannot be correlated with depression scores. ${ }^{55}$ Another found that although there was a significant increase in daily salivary cortisol following 8 weeks of treatment, this change was not significantly associated with depression scores. ${ }^{66}$ 
However, a recent study that compared $\mathrm{HCV}$ patients who were and were not taking IFN- $\alpha$ found that treatment was associated with a relative flattening of the diurnal slope for both salivary cortisol and adrenocorticotrophin-releasing hormone production and that flattening of the cortisol slope was associated with depressive symptoms, particularly somatic depressive symptoms. ${ }^{67}$ Issues leading to mixed results in these studies include the low number of participants and different measurements of cortisol (plasma cortisol and salivary cortisol). Another issue is the differing analyses employed by investigators with Raison et $\mathrm{al}^{67}$ analyzing the daily cortisol slope, whereas Wichers et a $1^{66}$ analyzed daily average cortisol levels.

\section{Cytokine mechanisms}

As IFN- $\alpha$ is a cytokine designed to affect immune system functioning, some researchers have chosen to look at baseline immune system functioning and the relative increase in cytokines induced by treatment to see if that had any effect on the subsequent development of depression.

One of the main questions regarding biological risk factors for development of an IFN- $\alpha$-induced depression is how the immune system, which is a peripheral system, can exert effects on mood and behavior via the central nervous system (CNS). There are two main theories regarding this question; the first supposes that cytokines may enter the brain. There are a number of ways in which cytokines may enter the brain. The first is via circumventricular regions where the blood-brain barrier (BBB) is more permeable ${ }^{68}$ such as the organum vasculosum of the lamina terminalis, with uptake mechanisms for cytokines such as IL-1 being demonstrated at the surface of the BBB. ${ }^{69,70}$ Active transport mechanisms for transportation into the brain are also being identified for cytokines, including IL- $1^{71}$ and tumor necrosis factor- $\alpha($ TNF- $\alpha) .{ }^{72}$ Another hypothesis concerns the induction of adhesion molecules such as vascular endothelial growth factor-1 in the brain endothelium, which increases the potential for circulating T-lymphocytes to cross the BBB. ${ }^{73}$

However, the second theory suggests that the immune system influences secondary factors that in turn interact with the CNS. ${ }^{32}$ In the second scenario, there is a complex interplay between stressors, the IDO-KYN pathway (see Figure 2), and factors that influence neuroplasticity in the development of cytokine-induced depression (see Figure 2). ${ }^{57,74,75}$

\section{Cytokines as a risk factor}

The role of cytokines in IFN- $\alpha$-induced depression is a complex one, with circulating cytokines, but not central cytokines,

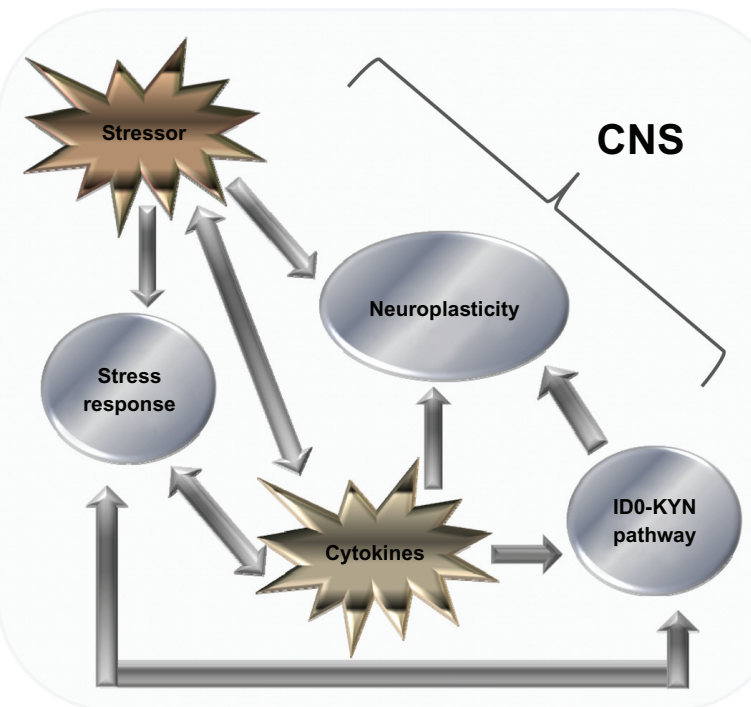

Figure 2 Cytokine-mediated pathways that influence the CNS. Diagram showing the various factors that influence the CNS. There is a complex relationship, the relationship with monoamines and the IDO-Kyn pathway, growth factors, and stress. Stressors and cytokines both increase the stress response, which is reflected by an increase in the amount of $\mathrm{CRH}$, both in the CNS and peripherally, which in turn activates $\mathrm{ACTH}$ and cortisol (CORT) levels. CRH also has a bidirectional relationship with serotonin (5-HT) levels, and gamma aminobutyric acid acts as a mediator for this process. 5-HT levels are also influenced by the production of IDO, which favors the production of the neurotoxin KYN over 5-HT. The stressor system and IDOKYN pathway both lead to a reduction in 5-HT. Cytokines also influence oxidative and apoptotic mechanisms, leading to a reduction in growth factors such as brainderived neurotrophic factor, which in turn leads to impaired neuroplastic processes and decreased neurogenesis, as well as cytokines having an indirect effect on growth factor levels; stress has also been shown to have a direct effect. The culmination of these three pathways can lead to the development of major depression. Copyright (C) 2005, Elsevier. Adapted with permission from Hayley S, Poulter MO, Merali Z, Anisman $\mathrm{H}$. The pathogenesis of clinical depression: stressor- and cytokine-induced alterations of neuroplasticity. Neuroscience. 2005;135(3):659-678.

Abbreviation: $\mathrm{CRH}$, corticotrophin-releasing hormone.

appearing to have a relationship with depression scores. It was found that a higher IL-6 response at weeks $2-4$ was predictive of a higher MADRS score 4-6 months later..$^{40}$ Another study found that pretreatment levels of circulating IL-6 predicted the incidence of developing a major depressive disorder (MDD), and using regression analyses, the authors were able to predict the following month's Beck Depression Inventory (BDI) score using the previous month's IL-6 levels. ${ }^{41}$ Other studies have also found that a significantly increased baseline concentration of IL- 6 can be a predictor for subsequent depression. ${ }^{76}$ In addition to IL-6, other peripheral cytokines shown to correlate with an increase in depressive symptoms include the soluble IL-2 receptor and TNF- $\alpha,{ }^{66}$ with baseline levels of soluble IL-2 receptor and IL-10 being significantly increased in those patients who went on to develop depression. ${ }^{76}$ Another study that examined the relative importance of cytokines in depressive symptomology found that TNF- $\alpha$ and not IL- 6 was correlated with mood scores. ${ }^{67}$

However, when central levels of cytokines were measured in CSF while IFN- $\alpha$ induced a significant increase in 
the cytokines IL-6 and monocyte chemoattractant protein-1 (MCP-1), only CSF concentrations of 5-hydroxyindoleacetic acid predicted depressive symptoms. ${ }^{57}$ These findings could mean that only peripheral cytokines can be correlated with depressive symptoms, possibly due to the influence of peripheral cytokines on the neurovegetative symptoms of depression.

Recent research is attempting to determine the specific neurobehavioral effect of cytokines by acknowledging the multidimensional nature of MDD as a disorder consisting of a number of specific subgroups of symptoms. ${ }^{47}$ There is a possibility that cytokines may be involved in certain aspects of the depressive syndrome, such as sleep and appetite changes, rather than being the central neurobiological cause of depression. ${ }^{35}$ There has been evidence that IL-6 may be linked in with poor sleep quality in patients taking IFN- $\alpha,{ }^{41}$ with poor sleep quality being identified as a predicting factor for the development of a subsequent depression. ${ }^{41,77}$

There is substantive support for the role of biological risk factors in the development of the IFN- $\alpha$-induced depression. However, as results are not always conclusive and replicable, there is a possibility that this risk factor acts in conjuntion with other factors in the development of a depression.

\section{Genetic risk factors}

Biological mechanisms responsible for IFN- $\alpha$-induced depression will inevitably be influenced by underlying genetic vulnerability. Several genetic polymorphisms have been associated with an increased risk of developing depression. One of the most reproducible findings in this area is the observation that people who have the short allele in the functional $5^{\prime}$ promoter of the serotonin transporter gene (5-HTTLPR) are significantly more likely to be depressed in response to a major life event ${ }^{78,79}$ or in general ${ }^{80,81}$ than those people with the long version of this allele. Other genes implicated in depression are involved in the functioning of glucocorticoids, ${ }^{82}$ neuronal growth, ${ }^{83}$ dystonia, ${ }^{84}$ as well as the 5 -HT1 A autoreceptor gene, ${ }^{85}$ and the IL-1 $\beta$ gene $^{86}$ among others. ${ }^{87,88}$

These genes offer potential avenues for researchers looking to identify genetic risk factors to explore, and recent research conducted in $\mathrm{HCV}$ patients taking IFN has identified a number of genes that have been shown to correlate with depression (see Table 2). The 5-HT transporter gene has been shown to have a role in the development of depression in addition to polymorphisms in the interferon receptor-A1 gene, the apoloprotein (APOE) $\varepsilon 4$ allele, the cyclooxygenase 2 (COX2) and phospholipase A2 (PLA2) genes, and the IL-6 gene in patients taking IFN (see Table 2).
A number of researchers have shown that the short version of the 5-HTTLPR increases the risk of developing a depressive episode when undertaking IFN- $\alpha$ therapy. ${ }^{92,93}$

One recent study demonstrates the difficulty in generalizing results across different ethnic groups, with non-Hispanic Caucasians and Hispanic Caucasians both showing opposite risk polymorphisms of the 5-HTTLPR gene for depression, ${ }^{93}$ meaning that results from different ethnic groups should be interpreted with caution. These studies are also limited by the different types of depression scales used such as the overall Hospital Anxiety and Depression Scale (HADS) score, ${ }^{91}$ BDI, ${ }^{92-94}$ Zung Self-Rating Depression Scale (SDS), ${ }^{95}$ and BDI or SDS. ${ }^{89}$

Some genes appear to be related to a specific subgroup of depressive symptoms rather than the depressive disorder as a whole. Both the interferon receptor-A1 and PLA2 genes were associated primarily with somatic and neurovegetative symptoms. ${ }^{94,95}$ The APOE $\varepsilon 4$ allele was shown to be more so associated with symptoms of anger and irritability, ${ }^{90}$ with a recent study showing that a TNF- $\alpha$ polymorphism is also associated with labile anger and fatigue but not depression. ${ }^{96}$ The 5-HTTLPR, IL-6, and 5-HT1A genes were associated with overall depression scores. ${ }^{89,91,92}$ The 5-HTTLPR gene was also associated with sleep quality, ${ }^{92}$ which is in itself a predictor of depression. ${ }^{41,77}$ Further work demonstrated that both the 5-HTTLPR and IL-6 genes are not associated with fatigue scores. ${ }^{92}$

These studies show that different genes are possibly involved in different aspects of the depressive disorder. There is also the possibility that the future may yield some useful genetic markers so that clinicians may identify 'at-risk' individuals and also identify what subgroups of symptoms patients may experience.

\section{Demographic and social risk factors}

Several demographic factors potentially impact on the development of depression, ${ }^{62}$ including age, gender, ethnicity, and education level. However, there is no consensus as to whether any of these factors impact on the development of depression in patients taking IFN- $\alpha$ (see Table 3).

The problems with these studies are demonstrated by the work of Pierucci-Lagha et $\mathrm{al}^{93}$ who found that there was a significant difference between ethnic groups at week 12 but that this difference was no longer significant at week 20 . This could mean that the observed significant difference was an artifact rather than a true reflection of ethnic differences in depression, and thus all other results regarding ethnicity must be interpreted with caution. 
Table 2 Genetic risk factors

\begin{tabular}{|c|c|c|c|}
\hline Authors & No. of participants & Areas assessed & Results \\
\hline Bull et $\mathrm{a}^{89}$ & 98 & $\begin{array}{l}\text { Relationship between polymorphisms } \\
\text { in the IL- } 6 \text { and } 5 \text {-HTT genes and } \\
\text { symptoms of depression and fatigue } \\
\text { in patients taking IFN- } \alpha\end{array}$ & $\begin{array}{l}\text { IL-6: A 'low IL-6' synthesizing genotype was associated with } \\
\text { significantly fewer depressive symptoms during treatment } \\
\text { 5-HTT: A 'high transcription } \\
\text { 5-HTT' genotype was associated also with fewer } \\
\text { depressive symptoms } \\
\text { The authors propose an interaction in these genes offering } \\
\text { a protective role }\end{array}$ \\
\hline Gochee et al ${ }^{90}$ & 110 & $\begin{array}{l}\text { Association between APOE } \\
\text { genotypes and neuropsychiatric } \\
\text { symptoms in patients taking IFN- } \alpha\end{array}$ & $\begin{array}{l}\text { APOE } 4 \text { allele: More likely to be referred to a psychiatrist } \\
\text { and had more neuropsychiatric symptoms (more likely } \\
\text { to experience irritability, anger, and mood disturbances). } \\
\text { In addition, more likely to experience a neuropsychiatric } \\
\text { event sooner } \\
\text { Depression carrier I0 (38.5\%), noncarrier } 29(34.5 \%) \text {, } \\
\text { irritability I5/I7 (57.7\%/20.2\%), anxiety/other mood I5/I8 } \\
\text { (57.7\%/2I.4\%) prior psychiatric } 9 / 15 \text { ( } 34.6 \% / I 7.9 \%) \\
\text { However, this gene and a previous history of psychiatric } \\
\text { illness was not significant }\end{array}$ \\
\hline Kraus et $\mathrm{al}^{91}$ & 139 & $\begin{array}{l}\text { Investigate the impact of genetic } \\
\text { variations within the serotonin } \\
\text { system on likelihood of depression } \\
\text { development during treatment }\end{array}$ & $\begin{array}{l}\text { 5-HTIA receptor gene HTRIA variation: Those patients } \\
\text { homozygous for this gene were significantly more likely to } \\
\text { develop depression during treatment and have significantly } \\
\text { higher HADS scores when compared to patients who } \\
\text { carried 5-HTT or TPH2 polymorphisms }\end{array}$ \\
\hline Lotrich et $\mathrm{al}^{92}$ & 71 & $\begin{array}{l}\text { Influence of the serotonin } \\
\text { transporter gene in development of } \\
\text { depression in patients taking IFN- } \alpha\end{array}$ & $\begin{array}{l}\text { 5-HTTLPR: Those patients with the } L_{A} \text {-allele were less } \\
\text { likely to develop depression, whereas those patients who } \\
\text { displayed the } S / S \text { allele of this gene the most vulnerable to } \\
\text { developing depression. This increased rate of depression } \\
\text { in vulnerable patients was reported to be related to poor } \\
\text { sleep quality in carriers of the } S / S \text { allele }\end{array}$ \\
\hline Pierucci-Lagha et $\mathrm{al}^{93}$ & 1015 & $\begin{array}{l}\text { Assess the influence of a } \\
\text { polymorphism in the serotonin } \\
\text { transporter gene on subsequent } \\
\text { depression development }\end{array}$ & $\begin{array}{l}\text { 5-HTTLPR: 5-HTLLPR genotype moderated the } \\
\text { occurrence of depression in non-Hispanic Caucasians and } \\
\text { Hispanic Caucasians but not African-Americans } \\
\text { In non-Hispanic Caucasians, the L' allele was associated } \\
\text { with depression scores, whereas in Hispanic Caucasians, } \\
\text { the S'-allele was associated with depression scores } \\
\text { In both these populations, the 5-HTTLPR genotype } \\
\text { interacted with psychiatric history and time to produce } \\
\text { higher depression scale scores }\end{array}$ \\
\hline Su et al $^{94}$ & 132 & $\begin{array}{l}\text { Ascertain the influence of } \\
\text { polymorphisms in genes that regulate } \\
\text { the metabolism of polyunsaturated } \\
\text { fatty acids (PLA2 and COX2) }\end{array}$ & $\begin{array}{l}\text { COX2 rs } 4648308 \text { and PLA2 Banl GG genotypes: Those } \\
\text { patients who had the COX2 rs } 4648308 \text { allele were } \\
\text { significantly more likely to develop a depression. The PLA2 } \\
\text { Banl polymorphism was associated with a higher severity of } \\
\text { the somatic symptoms of depression }\end{array}$ \\
\hline Yoshida et al ${ }^{95}$ & 50 & $\begin{array}{l}\text { Development of depression in } \\
\mathrm{HCV} \text { patients taking IFN } \alpha \text { and } \\
\text { how this relates to four promoter } \\
\text { polymorphisms of the IFNARI gene }\end{array}$ & $\begin{array}{l}\text { GT promoter repeat dinucleotide microsatellite } \\
\text { polymorphism of the IFNARI gene: Patients with the } \\
5 / I 4 \text { genotype of the GT repeat dinucleotide microsatellite } \\
\text { polymorphism showed greater differences in the baseline } \\
\text { to maximum difference in the SDS index score of } \\
\text { neurovegetative/somatic symptoms }(P=0.0084)\end{array}$ \\
\hline
\end{tabular}

Notes: Studies that examine the impact of genetic risk factors on the development of depression during treatment with IFN- $\alpha$.

The only social risk factor that appears to influence levels of depression is that of social support, with lower levels leading to a significantly higher risk of developing a depression. ${ }^{24}$ Support for the involvement of this demographic factor also comes from research conducted in patients with malignant melanoma, where patients who employed effective coping strategies and had social support were less likely to become depressed. ${ }^{105}$ However, more work needs to be conducted in this area before any concrete conclusions can be drawn.

\section{Treatment-related risk factors}

Higher doses of IFN- $\alpha$ are associated with more numerous side effects. ${ }^{106,107}$ However, it is not clear whether this 
Table 3 Demographic risk factors

\begin{tabular}{|c|c|c|}
\hline Risk factor & Evidence for & Evidence against \\
\hline Age & $\begin{array}{l}\text { Castera et a }{ }^{97} \\
\text { Patients who developed mood disorders during treatment were } \\
\text { significantly younger (mean age } 43 \text { ) than those who did not (mean age 48) } \\
\text { Horikawa et al }\left.\right|^{98} \\
\text { Only risk factor in their study where } 23.2 \% \text { of patients developed } \\
\text { depression was advanced age } \\
\text { Evon et al }{ }^{24} \\
\text { Patients who developed a depression were significantly younger than } \\
\text { those who did not }\end{array}$ & $\begin{array}{l}\text { Hauser et al }{ }^{99} \\
\text { Of the } 33 \% \text { of their patients who became } \\
\text { depressed, there was no difference in age to those } \\
\text { who did not become depressed } \\
\text { Miyaoka et al }{ }^{100} \\
\text { Martin-Santos et al }{ }^{101} \\
\text { Raison et al }{ }^{62} \\
\text { Su et a }{ }^{94}\end{array}$ \\
\hline Education level & $\begin{array}{l}\text { Martin-Santos et al }{ }^{101} \\
\text { Those people with only a primary education level (ie, lower levels } \\
\text { of education) were significantly more likely to develop a depressive } \\
\text { or anxiety disorder }\end{array}$ & Su et a $\left.\right|^{94}$ \\
\hline Gender & $\begin{array}{l}\text { Gohier et al }{ }^{102} \\
\text { Sixty-four percent of women developed a depression on treatment } \\
\text { Su et a }{ }^{94} \\
\text { Significantly more women }(52.4 \%) \text { than men }(23.8 \%) \text { developed } \\
\text { a depression on treatment }\end{array}$ & $\begin{array}{l}\text { Bonaccorso et a }\left.\right|^{103} \\
\text { Castera et } \mathrm{a}^{97} \\
\text { Hauser et } \mathrm{a}^{99} \\
\text { Lotrich et al }\left.\right|^{104} \\
\text { Miyaoka et al }{ }^{100} \\
\text { Martin-Santos et al }\left.\right|^{101} \\
\text { Raison et a }\left.\right|^{62}\end{array}$ \\
\hline Ethnicity & $\begin{array}{l}\text { Hauser et al }{ }^{99} \\
\text { The only demographic baseline characteristic that yielded a significant } \\
\text { difference was that there were significantly more Caucasians (76.9\%) } \\
\text { who developed depression than African-Americans (23.1\%) } \\
\text { Martin-Santos et al }{ }^{101} \\
\text { Significantly more people who developed a depressive or anxiety } \\
\text { disorder on treatment were immigrants (64\%) compared with } \\
\text { nonimmigrants (37\%) } \\
\text { Pierucci-Lagha et al }{ }^{93} \\
\text { At } 12 \text { weeks, non-Hispanic Caucasians had a significantly higher } \\
\text { level of depression (39\%) than African-Americans ( } 29 \%) \text { or Hispanic } \\
\text { Caucasians (28\%). However, this significant difference disappeared at } \\
20 \text { weeks }\end{array}$ & $\begin{array}{l}\text { Evon et a }{ }^{24} \\
\text { There was no significant difference in the } \\
\text { development of depression between those } \\
\text { patients who were Caucasian and those who were } \\
\text { African-American }\end{array}$ \\
\hline Social support & $\begin{array}{l}\text { Evon et a }{ }^{24} \\
\text { Those patients who reported having lower levels of social support } \\
\text { were significantly more likely to develop depression than those who } \\
\text { had such support }\end{array}$ & - \\
\hline
\end{tabular}

Notes: Studies where impact of demographic risk factors was investigated with relation to depression occurrence during IFN- $\alpha$ treatment.

observed dose effect also holds for the development of depression (see Table 4). In general, rates of depression in patients taking IFN- $\alpha$ for HCV vary from $0 \%{ }^{109,118}$ to up to $50 \%{ }^{21,62,97,99-101,104,108,113,116}$ Oncology patients taking up to five times the dose of IFN- $\alpha$ than those patients infected with $\mathrm{HCV}$ are prescribed have similar rates of depression from $5 \%{ }^{119}$ up to $50 \% .{ }^{120}$ Given that the doses of IFN- $\alpha$ given to the two populations are very different, there does not appear to be a convincing difference regarding the impact of dose on development of depression. However, a potential confounding factor is the retrospective design of most of these studies. This design can yield lower rates of depression than prospective depression-specific design, used by many contemporary researcher-led studies, ${ }^{62}$ perhaps also explaining the lower rates of depression seen in some of the studies in Table $4 .{ }^{107}$
Other treatment-related factors such as coprescription of ribavirin and length of treatment do not seem to yield a general consensus on the impact of treatment-related risk factors on depression. This suggests that while treatment factors impact on the 'sickness' aspect of sickness behavior, that is, those somatic complaints that follow an infection or illness (see Table 1), there is little evidence suggesting that they impact hugely on the behavioral aspects of sickness behavior, one of which is depression.

\section{Psychobehavioral risk factors}

Risk factors implicating both psychological and behavioral vulnerabilities as being predictors of subsequent depression have been arguably the most researched in this field as simple reasoning would suggest that if a drug induces psychobehavioral side effects, a pre-existing vulnerability 
Table 4 Studies reviewed to assess whether treatment-related risk factors can be associated with development of depression in patients prescribed IFN- $\alpha$

\begin{tabular}{|c|c|}
\hline Risk factor & Evidence for \\
\hline Dose of interferon & 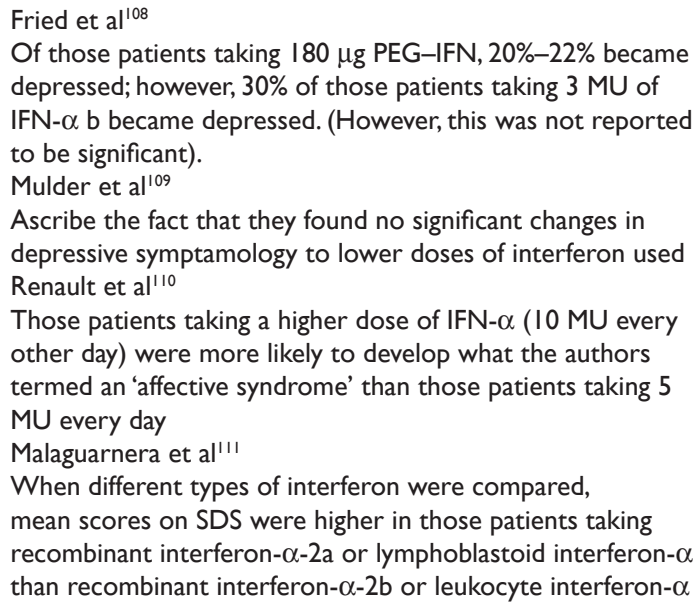 \\
\hline
\end{tabular}

Length of treatment $\quad-$

Retreatment following nonresponse

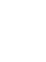

Evidence against

Horikawa et al ${ }^{98}$

No evidence that type and dose of interferon impacted on depression rates

lino 112

In patients taking three regimens of high-dose IFN treatment (10 MU over varying periods up to 14 weeks to a total of $480 \mathrm{MU}$ ). Rates of reported depression ranged from $4.8 \%$ to $7.1 \%$

Kraus et al ${ }^{113}$

There was no significant difference in reported rates of depression between those patients taking 5 MU IFN- $\alpha$ (33.3\%) and those taking $80-150 \mu \mathrm{g}$ PEG-IFN- $\alpha$ (40\%) Manns et al ${ }^{114}$

In a comparison of different dosing regimes of interferon, there was no significant difference in rates of depression between higher dose peginterefron plus ribavirin (3l\%), lower dose peginterefron + ribavirin (29\%), and interferon plus ribavirin (34\%)

Okanoue et al ${ }^{107}$

In a clinical study where patients were taking 6-10 MU of interferon, only $3.5 \%$ became clinically depressed Zeuzem et al ${ }^{115}$

There was no significant difference in reported rates of depression between those patients taking $180 \mu \mathrm{g} /$ week of PEG-IFN- $\alpha$ (I6\%) and those patients taking 3 MU IFN- $\alpha$ (23\%). Clinically depressed

Castera et a ${ }^{97}$

There was no significant difference in rates of depression between those on treatment for 24 weeks (53\%) and those on treatment for 48 weeks ( $47 \%$ )

Hauser et al ${ }^{99}$

Median time to depression in those patients who

developed it was 12 weeks

Horikawa et al ${ }^{98}$

$73.9 \%$ of patients developed depression within first 8 weeks

Robaeys et al ${ }^{116}$

Depression occurred in patients between 4 and 26 weeks, with the mean time to depression 10 weeks

Quarantini et al ${ }^{117}$

In nonresponder patients, rates of IFN- $\alpha$-induced depression were comparable to studies in treatment naive patients with $10 \%$ of 30 patients being diagnosed with depression during treatment
Ribavirin
Raison et al ${ }^{62}$
Patients who received weight-based dosing of ribavirin $(800-1400 \mu \mathrm{g} /$ day) were significantly more likely to develop moderate to severe depressive symptoms than those people who received a standard dose $(800 \mu \mathrm{g} /$ day $)$

Davis et al $^{12}$

No significant difference between development of depression in those patients taking IFN (I I\%) and those patients taking IFN + ribavirin (16\%)

Fried et al ${ }^{108}$

No difference in rates of depression between two groups both receiving PEG-IFN- $\alpha$ with either ribavirin (22\%) or Placebo (20\%)

McHutchison et al ${ }^{21}$

There were no significant differences between the rates of depression in those people taking a standard dose of IFN (25\%-37\%) and those patients taking interferon and ribavirin $(32 \%-36 \%)$ 
to developing a psychiatric disorder (be that history, current diagnosis, behavioral problems, or higher than normal rating on a psychiatric scale) should lead such patients to be more 'at risk' than others. Following an early observation that higher pretreatment scores on a depressive rating scale led to cancer patients having a higher risk of becoming depressed, ${ }^{121}$ several studies on HCV patients have explored this observation in more detail, with an emerging consensus that this risk factor results in patients being significantly more likely to develop depression when taking IFN- $\alpha$ (see Table 5). It could, however, also be argued that this 'risk factor' has the most support simply because it has been the most investigated. This risk factor goes hand in hand with findings which suggest that people with a past history of psychiatric illness, in particular MDD, are more vulnerable to becoming depressed on treatment. ${ }^{62,97}$ The research summarized in Table 5 suggests that some kind of 'subsyndromal' depression could leave people more susceptible to developing an IFN- $\alpha$-induced depression.

It has been shown that those people who become depressed on treatment are more likely to have an increased baseline score on a depression scale (see Table 5). Raison et $\mathrm{al}^{127}$ propose that all people prescribed IFN- $\alpha$ develop a side effect profile, comprised of neurovegetative symptoms (those somatic aspects of sickness behavior) or depressivespecific symptoms (those symptoms specific to the behavioral parts of sickness behavior). Both of these side effect profiles are measured by depression rating scales. Thus, if a person scores highly at baseline on one of these scales, it would stand to reason that these scores would remain throughout the course of the treatment and that some additional treatment-related factors would also come into play. The additive effect would mean that this subset of patients would be more at risk of being diagnosed with a depressive disorder due to elevated scores on a depression rating scale. Should this be the case, then all patients would experience an increase in scores on a depression rating scale relative to time, which is something that much of the literature seems to support. ${ }^{23,25,104,108,111,113,114,125,128-134}$ In fact, some researchers have pinpointed a relative increase in somatic components of depressive rating scales as being primarily responsible for the increase in scores seen in many patients. ${ }^{46}$ However, many recent studies have become aware of the potential confounds associated with using only depression rating scales; the range cannot be deleted and so diagnose MDD using DSM-IV-TR criteria. In order to meet criteria for diagnosis of MDD, patients are required to show depressed mood for most of the days, nearly every day, and/or demonstrate a direct loss in interest in activities every day for 2 weeks. Neither of these factors are somatic in nature, although it could be said that they may result from a primarily somatic complaint.

Psychiatric morbidity at baseline is perhaps the most intriguing of all research in this area. Evidence, however, is varied with some studies finding no difference in development of depression in patients taking IFN- $\alpha$, regardless of psychiatric history, and some indicating that patients are more likely to develop depression should they exhibit psychiatric vulnerability (see Table 5). This in part could be related to the fact that many of the studies that investigate a predefined 'at-risk' population such as those who have pre-existing psychiatric disorder are often coprescribed additional support at baseline with SSRIs and therapy. ${ }^{29-31}$

Another important issue with this population is whether researchers are investigating the incidence of total depression or 'new' depression only. Hauser et $\mathrm{al}^{99}$ reported an incidence of $6 \%$ of 'new' depression in the psychiatric group, which was not significant when compared against the incidence of 'new' depression in the other groups examined. However, if people depressed prior to treatment were included, then the total incidence of depression in this group was $44 \%$, a much higher rate than in other groups. Some studies that have found evidence for a past psychiatric history impacting on IFN- $\alpha$-induced depression include people who were diagnosed as being depressed prior to the start of treatment (see Table 5). This begs the question of which approach is better. If examining a 'psychiatric group', then a substantial proportion of this group may have depression, and removing this group from subsequent analyses will impact upon the level of depression observed. At the same time, however, these studies are supposedly examining IFN- $\alpha$-induced depression, and if a person is depressed when commencing treatment, the depression observed while on treatment is not an IFN- $\alpha$-induced phenomenon and should not be included.

The approach adopted by Hauser et $\mathrm{al}^{99}$ is perhaps the most sensible, given this dilemma. They report their results in terms of 'new depression' but also mention that those depressed prior to treatment were more likely to develop moderate or severe depression compared to patients in other groups, thus providing evidence that IFN- $\alpha$ may increase depressive symptoms relative to the baseline that people begin treatment at. Thus, people with a lower 'baseline depression' will have an increase in depressive symptoms, but this is not always necessarily enough of an increase to mean a diagnosis of depression. However, those people with 

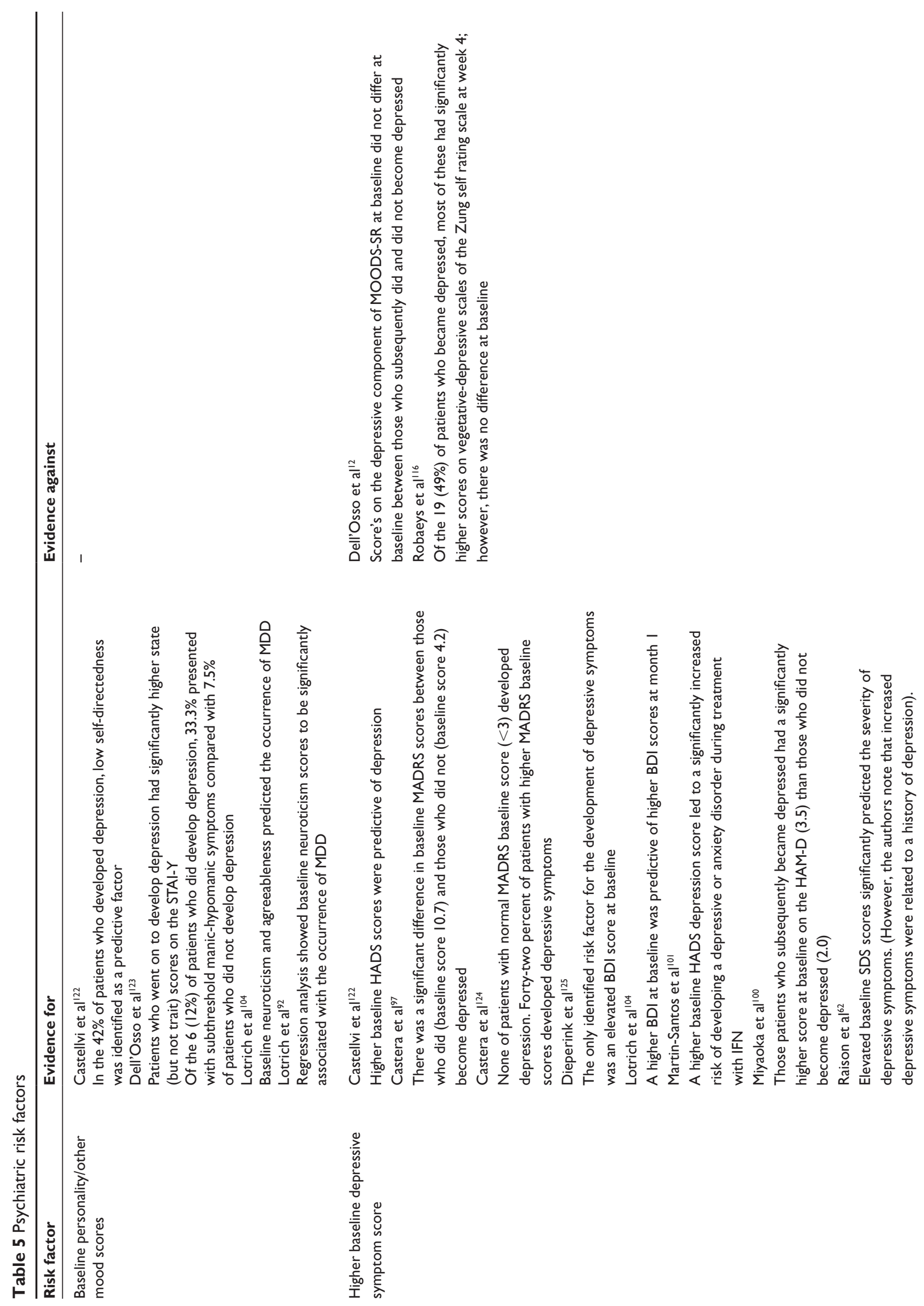

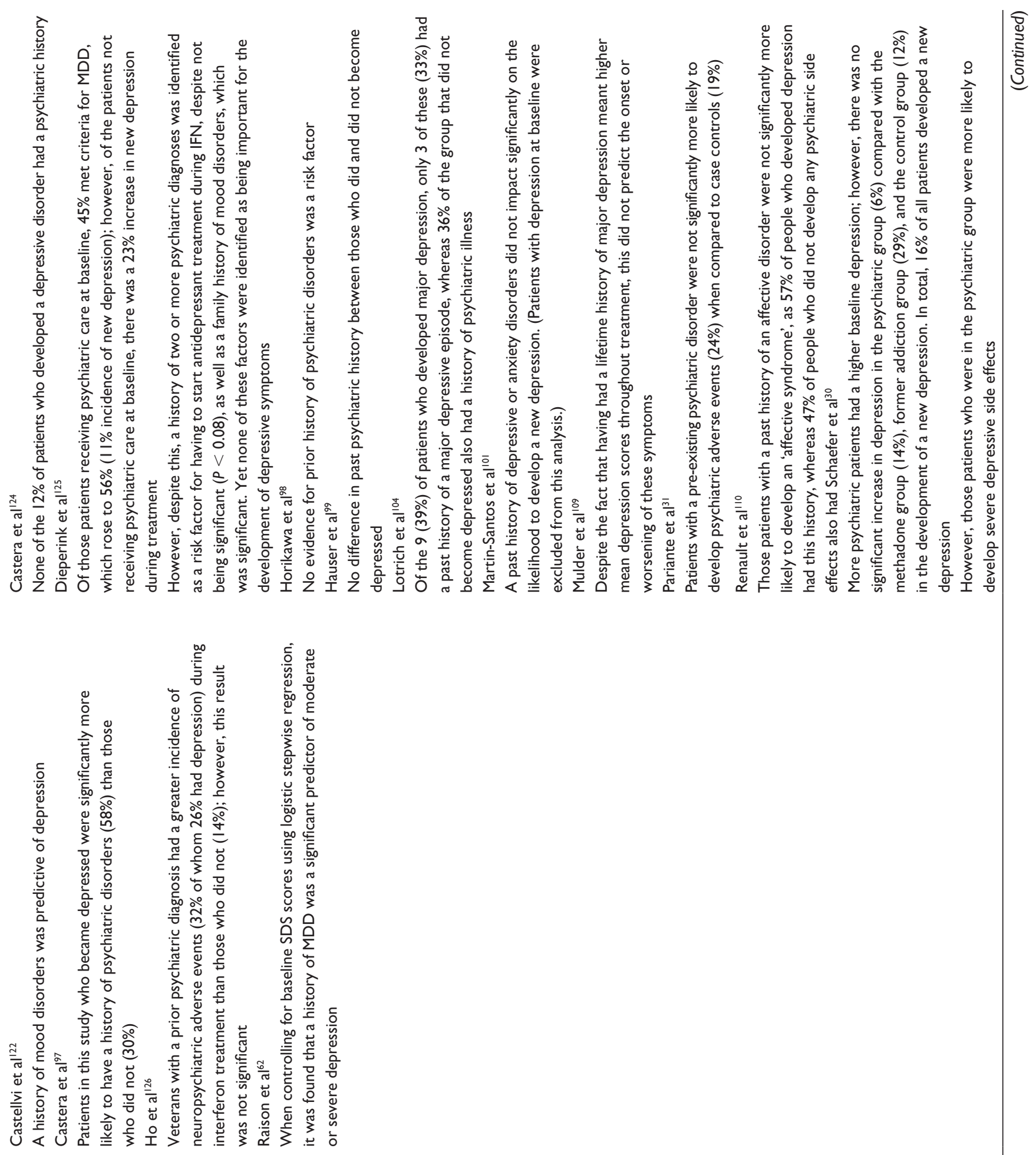

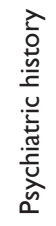

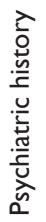




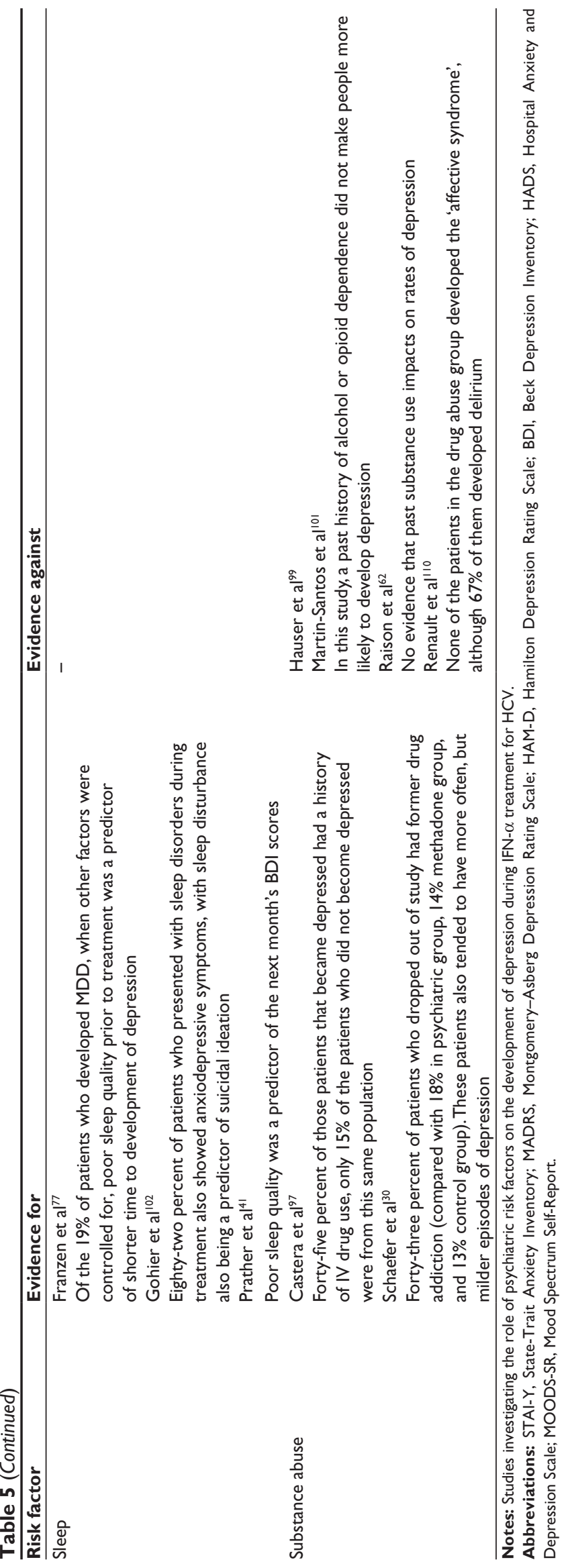

higher depression scores when commencing treatment will have the same kind of increase in depressive symptoms leading, in their case, to a diagnosis of depression.

Another risk factor that has increasing support is personality, with those individuals who have low self-directedness ${ }^{122}$ and high neuroticism ${ }^{92,104}$ being more likely to become depressed on treatment. The likelihood is that these personality factors interact with other psychobehavioral risk factors; however, more research needs to be conducted in order to determine this.

A behavioral risk factor that is gaining increasing interest from researchers is the impact of sleep disorders on the subsequent development of depression. Studies have shown that those patients who exhibit higher scores on the Pittsburgh Sleep Quality Index at baseline are more likely to develop MDD in a shorter time span, ${ }^{77}$ with sleep disturbance on treatment being a predictive factor for subsequent depression scale scores ${ }^{41}$ and suicidal ideation. ${ }^{102}$ However, a recent literature review on sleep disturbance in HCV states that the presence of insomnia in this cohort is influenced by underlying psychiatric comorbidity such as depression. ${ }^{122}$ This could mean that sleep disturbance interacts with other risk factors in determining the possible risk of developing depression in individuals. This idea is supported by Lotrich et $\mathrm{al}^{12}$ who found that when assessed alone, baseline sleep quality and BDI could predict depression; however, when Pittsburgh Sleep Quality Index and BDI scores were combined with 5-HTTLPR genotype, the effect of sleep and depression scale scores were diminished and only genotype had a significant impact on the development of depression.

The area of psychobehavioral risk factors impacting on subsequent development of IFN- $\alpha$-induced depression is perhaps the most convincing in terms of evidence gathered and rationale supplied by researchers. This risk factor is inevitably influenced by genetic and/or biological vulnerabilities.

\section{Limitations}

\section{Limitations of cited studies}

Many of the studies examined are retrospective and have only identified 'risk factors' following patients' completion of treatment. It could, therefore, be argued that it is easy to retrospectively identify a risk factor using statistics to compare 'depressed' and 'nondepressed' groups. In fact, a prospective depression-specific design rather than the retrospective general design often employed in clinical trials generally yields much higher rates of depression. ${ }^{135}$ Despite this, a risk factor might only be identified using a prospective depression-specific design, and following identification of that risk factor, other studies could have the effect of that 
particular risk factor on the development of depression as their primary hypothesis. This has certainly been the case with many studies on psychiatric side effects, and this area of research has much stronger empirical evidence supporting it than others (eg, demographic risk factors, which when examined in a study, appears to be an afterthought examined only retrospectively). Paradoxically, many studies have focused from the outset on the side effect of depression and will often find higher rates of depression, as they are 'on the look out' for this specific side effect. Studies of general side effects rather than the specific side effect of depression have found lower rates of depression. It may be the same with other risk factors. Should researchers and clinicians be more aware that certain risk factors could lead to an increased likelihood of depression being developed, depression in these individuals may be diagnosed more quickly. Many of these studies employ scales to examine depressive symptoms, and these scales are often high in somatic items, which because of IFN- $\alpha$ being a drug that induces a 'sickness behavior', many patients taking this drug will score highly on these items simply because they are sick, rather than being depressed per se. ${ }^{46}$ It will be important in future studies to determine the subscale loads of those items that are somatic or affective.

When assessing the role of the various biological and genetic risk factors identified in this review, there are some key issues that limit the interpretation of results. Many of the biological risk factors identified were not readily identifiable at baseline and instead are correlated with depressive symptoms after the induction of therapy. Another issue is the problem of correlating mood scores with a biomarker; high scores on a depression scale are not neccesarily representative of a depressive disorder and could instead be linked in to higher somatic symptoms. Some studies have shown that their biomarker of interest is preferentially correlated with somatic symptoms, ${ }^{67,94,95}$ and future work should determine which cluster of symptoms each biomarker is associated with. The majority of studies examined in this review chose to conduct correlational and regression analysis, with no studies comparing between groups who did and did not develop a depression. In future, it would be interesting to conduct analyses that include all comparisons in order to gain a full appreciation of the role of biomarkers in IFN- $\alpha$-induced depression.

Moreover, in issues relating to experimental design, there is the simple, yet often ignored issue that many patients who have $\mathrm{HCV}$ are more depressed than a healthy population; in fact, rates of depression in HCV patients can be as high as $40 \% .{ }^{136}$ Yates and Gleason ${ }^{137}$ found that in a study of 78 patients who were $\mathrm{HCV}$ positive, the main reasons for being referred for psychiatric consultation were showing psychiatric symptoms, consultations either prior to listing for liver transplantation and/or therapy with IFN- $\alpha$, and that the lowest number of patients that were referred for treatment in this group were those patients receiving IFN- $\alpha$ who had developed depressive symptoms. Furthermore, populations acquiring $\mathrm{HCV}$ tend to be from backgrounds that can lead them to have a higher level of depression regardless of treatment with IFN- $\alpha .{ }^{138}$ This evidence demonstrates that the HCV population is a vulnerable group generally and that focusing on only treatment-associated problems may lead clinicians and researchers alike to underestimate those problems that are associated with $\mathrm{HCV}$ itself.

\section{Limitations of review}

The results reported in this review are also limited by a number of factors. The first one being that only accessible articles were included within the review, and those articles that could not be accessed due to language constraints or inability to access full-text content were not included, which could have an impact on the risk factors identified and discussion of these factors.

In addition, there are some risk factors shown to impact on rates of depression that do not necessarily fit within the predefined categories and are not readily identifiable at baseline. Robaeys et al ${ }^{116}$ found that vegetative-depressive symptoms at week 4 of treatment were predictive of a subsequent diagnosis of MDD; however, there were no differences between groups at baseline. Likewise, decreased motor speed was associated with increased symptoms of depression and fatigue. ${ }^{134}$

There are also some biological factors that influence IFN$\alpha$-induced depression that were not explored in the literature review due to the paucity of literature in that area. One such factor is brain-derived neurotrophic factor, which has been shown to correlate with BDI scores. ${ }^{139}$

Other studies have examined risk factors in different patient populations. IFN- $\alpha$ is also used as treatment for certain cancers such as malignant melanoma, ${ }^{52,140}$ and there are studies within this population that support various risk factors that have been examined within this review such as HPA axis biomarkers, ${ }^{140}$ lower levels of tryptophan,,${ }^{52}$ higher pretreatment depression scores, ${ }^{141}$ low social support, sleep disturbance, pessimistic thoughts, and sadness. ${ }^{105}$

Only those studies that looked at risk factors for depression were examined. In future, it will be important to determine what protective factors prevent people from developing 
a depression. There is some evidence presented that social support may be a protective factor against the development of depression, ${ }^{24}$ and further research could determine what other protective factors are important.

When interpreting the results from this review, clinicians also need to be aware of the individual nature of depression and the varying risk factors that will cause each individual to become depressed. Even though this review has found strong evidence for certain risk factors, this does not mean to say that any person who experiences these factors will become depressed; it means that they are at a higher risk of developing depression than others who do not have these risk factors and thus extra assessment and support should be administered prior to commencement of treatment in those individuals who have been ascertained to be at risk of developing depression.

Finally, all results should be interpreted with caution due to the differing methodologies and analyses undertaken in all the studies within this review. While care has been taken to narrow the scope of the review by concentrating only on HCV patients, there are still differences between all the studies included here. These include the number of patients in each study, the type of statistical analysis run, the types of depression analysis undertaken (clinician rated and selfrated, depression scale or clinical diagnosis), and how each researcher defined depression (clinical diagnosis or cutoff point on depression scale). These should be recognized to be limiting factors in interpreting the results of this review.

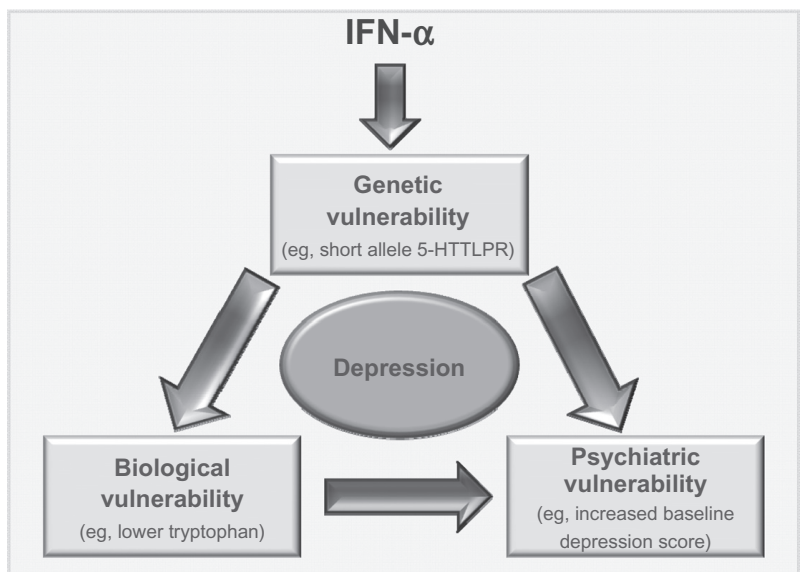

Figure 3 Interaction of risk factors. Model by which various risk factors could interact to possibly produce depression in those patients taking IFN- $\alpha$. It is possible that administration of IFN- $\alpha$ could lead to some underlying genetic vulnerability (eg, the short allele in 5-HTLLPR) impacting upon levels of a chemical such as tryptophan. This vulnerability, along with the biological response it could induce, would also interact with a psychiatric vulnerability. As these people have the genetic vulnerability, they are more likely to be depressed at baseline and/or have had a history of psychiatric disorders. All this would lead the person to be vulnerable to developing depression following administration of IFN.

\section{Conclusions}

The current climate of psychiatric research is one where there is an acknowledgment of the multidisciplinary factors that play into any psychiatric disorder. Current research is, therefore, focused on finding interactions between genetic, biological, demographic, and psychobehavioral factors that lead some people to be more vulnerable to developing psychiatric disorders than others. It would be very difficult to identify a single risk factor that would lead people to be more susceptible to becoming depressed on IFN- $\alpha$ than others. However, the most convincing research conducted in this area is that which has examined biological, ${ }^{41,57,58}$ genetic, ${ }^{89,91-93}$ and psychobehavioral ${ }^{41,62,77,92,97}$ risk factors, and it is no surprise that these three risk factors interact with one another (for an example of the way these three risk factors could interact to produce depression, see Figure 3).

Clinicians and researchers should be wary when trying to pinpoint one risk factor to concentrate on when attempting to identify 'at-risk' individuals. Instead, there should be an awareness of the complex interplay of biological, psychobehavioral, and genetic factors that lead some people to develop depression while taking IFN- $\alpha$ (see Figure 3). Two recent studies have examined interactions between genetic and psychobehavioral risk factors, ${ }^{92,93}$ demonstrating the need for more translational research in determining the relationship between different risk factors. Only when more research of this nature has been conducted, more concrete conclusions regarding the interaction and importance of individual risk factors can be determined.

Clinicians should attempt to assess people fully at baseline using as many tools available to them, such as depression rating scales, sleep disturbance questionnaires, psychiatric histories, and biological analysis of tryptophan and/or stress hormones. In future, it may also be possible to use genetic tools to identify individuals susceptible to development of IFN- $\alpha$-induced depression. HCV-infected patients taking IFN- $\alpha$ are undoubtedly a vulnerable population. Effective pretreatment screening for baseline risk factors combined with more effective support during treatment will enable health care workers to better identify patients at risk and provide the additional treatment required should depression develop, thus improving adherence rates and improving clearance of HCV infection.

\section{Acknowledgments}

The authors thank all staff in the Hepatology Centre, in particular, Barbara Hynes, Clodagh Quinn, and Helena Irish, as well as the Psychological Services Department at St James's 
Hospital, for their help in allowing us to better understand the patients' perspective of taking IFN- $\alpha$. Supported by the Health Research Board (Ireland).

\section{Disclosure}

The authors report no conflicts of interest in this work.

\section{References}

1. Shepard CW, Finelli L, Alter MJ. Global epidemiology of hepatitis C virus infection. Lancet Infect Dis. 2005;5(9):558-567.

2. Poynard T, Yuen MF, Ratziu V, Lai CL. Viral hepatitis C. Lancet. 2003;362(9401):2095-2100.

3. Esteban JI, Sauleda S, Quer J. The changing epidemiology of hepatitis C virus infection in Europe. J Hepatol. 2008;48(1):148-162.

4. Rantala M, van de Laar MJ. Surveillance and epidemiology of hepatitis B and C in Europe - a review. Euro Surveill. 2008;13(21). Available from http://www.eurosurveillance.org/ViewArticle.aspx?ArticleId=18880 Accessed 2010 Sep 18.

5. Alter MJ. Epidemiology of hepatitis C virus infection. World $J$ Gastroenterol. 2007;13(17):2436-2441.

6. Alazawi W, Cunningham M, Dearden J, Foster GR. Systematic review: outcome of compensated cirrhosis due to chronic hepatitis $\mathrm{C}$ infection. Aliment Pharmacol Ther. 2010;32(3):344-355.

7. Leone N, Rizzetto M. Natural history of hepatitis C virus infection: from chronic hepatitis to cirrhosis, to hepatocellular carcinoma. Minerva Gastroenterol Dietol. 2005;51(1):31-46.

8. Patel K, Muir AJ, McHutchison JG. Diagnosis and treatment of chronic hepatitis C infection. BMJ. 2006;332(7548):1013-1017.

9. Davis GL, Albright JE, Cook SF, Rosenberg DM. Projecting future complications of chronic hepatitis C in the United States. Liver Transpl. 2003;9(4):331-338.

10. Stark GR, Kerr IM, Williams BR, Silverman RH, Schreiber RD. How cells respond to interferons. Annu Rev Biochem. 1998;67:227-264.

11. Bacon BR. Managing hepatitis C. Am J Manag Care. 2004;10 Suppl 2: S30-S40.

12. Davis GL, Esteban-Mur R, Rustgi V, et al. Interferon alfa-2b alone or in combination with ribavirin for the treatment of relapse of chronic hepatitis C. International Hepatitis Interventional Therapy Group. N Engl J Med. 1998;339(21):1493-1499.

13. Cotler SJ, Wartelle CF, Larson AM, Gretch DR, Jensen DM, Carithers RL Jr. Pretreatment symptoms and dosing regimen predict side-effects of interferon therapy for hepatitis C. J Viral Hepat. 2000; 7(3):211-217.

14. Foster G, Mathurin P. Hepatitis C virus therapy to date. Antivir Ther. 2008;13 Suppl 1:S3-S8.

15. Kowdley KV. Hematologic side effects of interferon and ribavirin therapy. J Clin Gastroenterol. 2005;39 Suppl 1:S3-S8.

16. Ong JP, Younossi ZM. Managing the hematologic side effects of antiviral therapy for chronic hepatitis C: anemia, neutropenia, and thrombocytopenia. Cleve Clin J Med. 2004;71 Suppl 3:S17-S21.

17. Capuron L, Miller AH. Cytokines and psychopathology: lessons from interferon-alpha. Biol Psychiatry. 2004;56(11):819-824.

18. Dieperink E, Willenbring M, Ho SB. Neuropsychiatric symptoms associated with hepatitis $\mathrm{C}$ and interferon alpha: a review. Am J Psychiatry. 2000;157(6):867-876.

19. Fukunishi K, Tanaka H, Maruyama J, et al. Burns in a suicide attempt related to psychiatric side effects of interferon. Burns. 1998;24(6): 581-583.

20. Janssen HL, Brouwer JT, van der Mast RC, Schalm SW. Suicide associated with alfa-interferon therapy for chronic viral hepatitis. $J$ Hepatol. 1994;21(2):241-243.

21. McHutchison JG, Gordon SC, Schiff ER, et al. Interferon alfa-2b alone or in combination with ribavirin as initial treatment for chronic hepatitis C. Hepatitis Interventional Therapy Group. N Engl J Med. 1998; 339(21):1485-1492.
22. Bernstein D, Kleinman L, Barker CM, Revicki DA, Green J. Relationship of health-related quality of life to treatment adherence and sustained response in chronic hepatitis C patients. Hepatology. 2002;35(3):704-708.

23. Kraus MR, Schafer A, Csef H, Faller H, Mork H, Scheurlen M. Compliance with therapy in patients with chronic hepatitis $\mathrm{C}$ : associations with psychiatric symptoms, interpersonal problems, and mode of acquisition. Dig Dis Sci. 2001;46(10):2060-2065.

24. Evon DM, Ramcharran D, Belle SH, Terrault NA, Fontana RJ, Fried MW. Prospective analysis of depression during peginterferon and ribavirin therapy of chronic hepatitis C: results of the Virahep-C study. Am J Gastroenterol. 2009;104(12):2949-2958.

25. Kraus MR, Schafer A, Schottker K, et al. Therapy of interferon-induced depression in chronic hepatitis $\mathrm{C}$ with citalopram: a randomised, doubleblind, placebo-controlled study. Gut. 2008;57(4):531-536.

26. Gleason OC, Fucci JC, Yates WR, Philipsen MA. Preventing relapse of major depression during interferon-alpha therapy for hepatitis $\mathrm{C}-\mathrm{a}$ pilot study. Dig Dis Sci. 2007;52(10):2557-2563.

27. Raison CL, Woolwine BJ, Demetrashvili MF, et al. Paroxetine for prevention of depressive symptoms induced by interferon-alpha and ribavirin for hepatitis C. Aliment Pharmacol Ther. 2007;25(10): $1163-1174$

28. Morasco BJ, Rifai MA, Loftis JM, Indest DW, Moles JK, Hauser P. A randomized trial of paroxetine to prevent interferon-alpha-induced depression in patients with hepatitis C. J Affect Disord. 2007;103(1-3): 83-90.

29. Schaefer M, Schwaiger M, Garkisch AS, et al. Prevention of interferonalpha associated depression in psychiatric risk patients with chronic hepatitis C. J Hepatol. 2005;42(6):793-798.

30. Schaefer M, Schmidt F, Folwaczny C, et al. Adherence and mental side effects during hepatitis $\mathrm{C}$ treatment with interferon alfa and ribavirin in psychiatric risk groups. Hepatology. 2003;37(2): 443-451.

31. Pariante CM, Orru MG, Baita A, Farci MG, Carpiniello B. Treatment with interferon-alpha in patients with chronic hepatitis and mood or anxiety disorders. Lancet. 1999;354(9173):131-132.

32. Dantzer R, Bluthe RM, Gheusi G, et al. Molecular basis of sickness behavior. Ann N Y Acad Sci. 1998;856:132-138.

33. Dantzer R, O'Connor JC, Freund GG, Johnson RW, Kelley KW. From inflammation to sickness and depression: when the immune system subjugates the brain. Nat Rev Neurosci. 2008;9(1):46-56.

34. Konsman JP, Parnet P, Dantzer R. Cytokine-induced sickness behaviour: mechanisms and implications. Trends Neurosci. 2002; 25(3):154-159.

35. Dunn AJ, Swiergiel AH, de Beaurepaire R. Cytokines as mediators of depression: what can we learn from animal studies? Neurosci Biobehav Rev. 2005;29(4-5):891-909.

36. Hart BL. Biological basis of the behavior of sick animals. Neurosci Biobehav Rev. 1988;12(2):123-137.

37. Charlton BG. The malaise theory of depression: major depressive disorder is sickness behavior and antidepressants are analgesic. Med Hypotheses. 2000;54(1):126-130.

38. Lotrich FE. Major depression during interferon-alpha treatment: vulnerability and prevention. Dialogues Clin Neurosci. 2009;11(4): 417-425.

39. Schiepers OJ, Wichers MC, Maes M. Cytokines and major depression. Prog Neuropsychopharmacol Biol Psychiatry. 2005;29(2): 201-217.

40. Bonaccorso S, Puzella A, Marino V, et al. Immunotherapy with interferon-alpha in patients affected by chronic hepatitis $\mathrm{C}$ induces an intercorrelated stimulation of the cytokine network and an increase in depressive and anxiety symptoms. Psychiatry Res. 2001;105(1-2): 45-55.

41. Prather AA, Rabinovitz M, Pollock BG, Lotrich FE. Cytokine-induced depression during IFN-alpha treatment: the role of IL- 6 and sleep quality. Brain Behav Immun. 2009;23(8):1109-1116.

42. Loftis JM, Hauser P. The phenomenology and treatment of interferoninduced depression. J Affect Disord. 2004;82(2):175-190. 
43. Maddock C, Landau S, Barry K, et al. Psychopathological symptoms during interferon-alpha and ribavirin treatment: effects on virologic response. Mol Psychiatry. 2005;10(4):332-333.

44. Capuron L, Dantzer R, Miller AH. Neuro-immune interactions in psychopathology with the example of interferon-alpha-induced depression. J Soc Biol. 2003;197(2):151-156.

45. Schaefer M, Engelbrecht MA, Gut O, et al. Interferon alpha (IFNalpha) and psychiatric syndromes: a review. Prog Neuropsychopharmacol Biol Psychiatry. 2002;26(4):731-746.

46. Trask PC, Esper P, Riba M, Redman B. Psychiatric side effects of interferon therapy: prevalence, proposed mechanisms, and future directions. $J$ Clin Oncol. 2000;18(11):2316-2326.

47. Loftis JM, Huckans M, Morasco BJ. Neuroimmune mechanisms of cytokine-induced depression: current theories and novel treatment strategies. Neurobiol Dis. 2010;37(3):519-533.

48. Elhwuegi AS. Central monoamines and their role in major depression. Prog Neuropsychopharmacol Biol Psychiatry. 2004;28(3): 435-451.

49. Owens MJ, Nemeroff CB. Role of serotonin in the pathophysiology of depression: focus on the serotonin transporter. Clin Chem. 1994; 40(2):288-295.

50. Maletic V, Robinson M, Oakes T, Iyengar S, Ball SG, Russell J. Neurobiology of depression: an integrated view of key findings. Int J Clin Pract. 2007;61(12):2030-2040.

51. Miura H, Ozaki N, Sawada M, Isobe K, Ohta T, Nagatsu T. A link between stress and depression: shifts in the balance between the kynurenine and serotonin pathways of tryptophan metabolism and the etiology and pathophysiology of depression. Stress. 2008;11(3):198-209.

52. Capuron L, Neurauter G, Musselman DL, et al. Interferon-alpha-induced changes in tryptophan metabolism. relationship to depression and paroxetine treatment. Biol Psychiatry. 2003;54(9):906-914.

53. Bonaccorso S, Marino V, Puzella A, et al. Increased depressive ratings in patients with hepatitis $\mathrm{C}$ receiving interferon-alpha-based immunotherapy are related to interferon-alpha-induced changes in the serotonergic system. J Clin Psychopharmacol. 2002;22(1): 86-90.

54. Maes M, Bonaccorso S, Marino V, et al. Treatment with interferonalpha (IFN alpha) of hepatitis $\mathrm{C}$ patients induces lower serum dipeptidyl peptidase IV activity, which is related to IFN alpha-induced depressive and anxiety symptoms and immune activation. Mol Psychiatry. 2001;6(4):475-480.

55. Fontana RJ, Kronfol Z, Lindsay KL, et al. Changes in mood states and biomarkers during peginterferon and ribavirin treatment of chronic hepatitis C. Am J Gastroenterol. 2008;103(11):2766-2775.

56. Russo S, Kema IP, Haagsma EB, et al. Irritability rather than depression during interferon treatment is linked to increased tryptophan catabolism. Psychosom Med. 2005;67(5):773-777.

57. Raison CL, Borisov AS, Majer M, et al. Activation of central nervous system inflammatory pathways by interferon-alpha: relationship to monoamines and depression. Biol Psychiatry. 2009;65(4): 296-303.

58. Raison CL, Dantzer R, Kelley KW, et al. CSF concentrations of brain tryptophan and kynurenines during immune stimulation with IFN-alpha: relationship to CNS immune responses and depression. Mol Psychiatry. 2010;15(4):393-403.

59. Kraus MR, Schafer A, Faller H, Csef H, Scheurlen M. Paroxetine for the treatment of interferon-alpha-induced depression in chronic hepatitis $\mathrm{C}$. Aliment Pharmacol Ther. 2002;16(6):1091-1099.

60. Dafny N, Yang PB. Interferon and the central nervous system. Eur $J$ Pharmacol. 2005;523(1-3):1-15.

61. Asnis GM, de La Garza R 2nd. Interferon-induced depression in chronic hepatitis $\mathrm{C}$ : a review of its prevalence, risk factors, biology, and treatment approaches. J Clin Gastroenterol. 2006;40(4): 322-335.

62. Raison CL, Borisov AS, Broadwell SD, et al. Depression during pegylated interferon-alpha plus ribavirin therapy: prevalence and prediction. J Clin Psychiatry. 2005;66(1):41-48.
63. Leonard BE. The HPA and immune axes in stress: the involvement of the serotonergic system. Eur Psychiatry. 2005;20 Suppl 1:S302-S306.

64. Anisman H. Cascading effects of stressors and inflammatory immune system activation: implications for major depressive disorder. J Psychiatry Neurosci. 2009;34(1):4-20.

65. Raison CL, Capuron L, Miller AH. Cytokines sing the blues: inflammation and the pathogenesis of depression. Trends Immunol. 2006;27(1): 24-31

66. Wichers MC, Kenis G, Koek GH, Robaeys G, Nicolson NA, Maes M. Interferon-alpha-induced depressive symptoms are related to changes in the cytokine network but not to cortisol. J Psychosom Res. 2007;62(2): 207-214.

67. Raison CL, Borisov AS, Woolwine BJ, Massung B, Vogt G, Miller AH. Interferon-alpha effects on diurnal hypothalamic-pituitary-adrenal axis activity: relationship with proinflammatory cytokines and behavior. $\mathrm{Mol}$ Psychiatry. 2010;15(5):535-547.

68. Maier SF, Watkins LR. Cytokines for psychologists: implications of bidirectional immune-to-brain communication for understanding behavior, mood, and cognition. Psychol Rev. 1998;105(1):83-107.

69. Begley DJ. The interaction of some centrally active drugs with the blood-brain barrier and circumventricular organs. Prog Brain Res. 1992;91:163-169

70. Ermisch A, Brust P, Kretzschmar R, Ruhle HJ. Peptides and blood-brain barrier transport. Physiol Rev. 1993;73(3):489-527.

71. Dunn AJ. Endotoxin-induced activation of cerebral catecholamine and serotonin metabolism: comparison with interleukin-1. JPharmacol Exp Ther. 1992;261(3):964-969.

72. Gutierrez EG, Banks WA, Kastin AJ. Murine tumor necrosis factor alpha is transported from blood to brain in the mouse. J Neuroimmunol. 1993;47(2):169-176.

73. Brown MD, Wick TM, Eckman JR. Activation of vascular endothelial cell adhesion molecule expression by sickle blood cells. Pediatr Pathol Mol Med. 2001;20(1):47-72.

74. Anisman H, Merali Z, Poulter MO, Hayley S. Cytokines as a precipitant of depressive illness: animal and human studies. Curr Pharm Des. 2005;11(8):963-972.

75. Hayley S, Poulter MO, Merali Z, Anisman H. The pathogenesis of clinical depression: stressor- and cytokine-induced alterations of neuroplasticity. Neuroscience. 2005;135(3):659-678.

76. Wichers MC, Kenis G, Leue C, Koek G, Robaeys G, Maes M. Baseline immune activation as a risk factor for the onset of depression during interferon-alpha treatment. Biol Psychiatry. 2006;60(1):77-79.

77. Franzen PL, Buysse DJ, Rabinovitz M, Pollock BG, Lotrich FE. Poor sleep quality predicts onset of either major depression or subsyndromal depression with irritability during interferon-alpha treatment. Psychiatry Res. 2010;177(1-2):240-245.

78. Caspi A, Sugden K, Moffitt TE, et al. Influence of life stress on depression: moderation by a polymorphism in the 5-HTT gene. Science. 2003;301(5631):386-389

79. Brown GW, Harris TO. Depression and the serotonin transporter 5-HTTLPR polymorphism: a review and a hypothesis concerning gene-environment interaction. J Affect Disord. 2008;111(1):1-12.

80. Hoefgen B, Schulze TG, Ohlraun S, et al. The power of sample size and homogenous sampling: association between the 5-HTTLPR serotonin transporter polymorphism and major depressive disorder. Biol Psychiatry. 2005;57(3):247-251.

81. Pezawas L, Meyer-Lindenberg A, Drabant EM, et al. 5-HTTLPR polymorphism impacts human cingulate-amygdala interactions: a genetic susceptibility mechanism for depression. Nat Neurosci. 2005;8(6):828-834.

82. Binder EB, Salyakina D, Lichtner P, et al. Polymorphisms in FKBP5 are associated with increased recurrence of depressive episodes and rapid response to antidepressant treatment. Nat Genet. 2004;36(12): 1319-1325.

83. Tadokoro K, Hashimoto R, Tatsumi M, Kosuga A, Kamijima K, Kunugi $\mathrm{H}$. The gem interacting protein (GMIP) gene is associated with major depressive disorder. Neurogenetics. 2005;6(3):127-133. 
84. Heiman GA, Ottman R, Saunders-Pullman RJ, Ozelius LJ, Risch NJ, Bressman SB. Increased risk for recurrent major depression in DYT1 dystonia mutation carriers. Neurology. 2004;63(4):631-637.

85. Lemonde $\mathrm{S}$, Turecki $\mathrm{G}$, Bakish $\mathrm{D}$, et al. Impaired repression at a 5-hydroxytryptamine $1 \mathrm{~A}$ receptor gene polymorphism associated with major depression and suicide. $J$ Neurosci. 2003;23(25): 8788-8799.

86. Rosa A, Peralta V, Papiol S, et al. Interleukin-1beta (IL-1beta) gene and increased risk for the depressive symptom-dimension in schizophrenia spectrum disorders. Am J Med Genet B Neuropsychiatr Genet. 2004;124B(1):10-14

87. Levinson DF. The genetics of depression: a review. Biol Psychiatry. 2006;60(2):84-92.

88. Shyn SI, Hamilton SP. The genetics of major depression: moving beyond the monoamine hypothesis. Psychiatr Clin North Am. 2010; 33(1):125-140

89. Bull SJ, Huezo-Diaz P, Binder EB, et al. Functional polymorphisms in the interleukin- 6 and serotonin transporter genes, and depression and fatigue induced by interferon-alpha and ribavirin treatment. Mol Psychiatry. 2009;14(12):1095-1104.

90. Gochee PA, Powell EE, Purdie DM, et al. Association between apolipoprotein E epsilon4 and neuropsychiatric symptoms during interferon alpha treatment for chronic hepatitis C. Psychosomatics. 2004;45(1):49-57.

91. Kraus MR, Al-Taie O, Schafer A, Pfersdorff M, Lesch KP, Scheurlen M. Serotonin-1A receptor gene HTR1A variation predicts interferon-induced depression in chronic hepatitis C. Gastroenterology. 2007;132(4):1279-1286.

92. Lotrich FE, Ferrell RE, Rabinovitz M, Pollock BG. Risk for depression during interferon-alpha treatment is affected by the serotonin transporter polymorphism. Biol Psychiatry. 2009;65(4):344-348.

93. Pierucci-Lagha A, Covault J, Bonkovsky HL, et al. A functional serotonin transporter gene polymorphism and depressive effects associated with interferon-alpha treatment. Psychosomatics. 2010;51(2): 137-148.

94. Su KP, Huang SY, Peng CY, et al. Phospholipase A2 and cyclooxygenase 2 genes influence the risk of interferon-alpha-induced depression by regulating polyunsaturated fatty acids levels. Biol Psychiatry. 2010;67(6):550-557.

95. Yoshida K, Alagbe O, Wang X, et al. Promoter polymorphisms of the interferon-alpha receptor gene and development of Interferon-induced depressive symptoms in patients with chronic hepatitis C: preliminary findings. Neuropsychobiology. 2005;52(2):55-61.

96. Lotrich FE, Ferrell RE, Rabinovitz M, Pollock BG. Labile anger during interferon alfa treatment is associated with a polymorphism in tumor necrosis factor alpha. Clin Neuropharmacol. 2010;33(4): 191-197.

97. Castera L, Constant A, Henry C, et al. Impact on adherence and sustained virological response of psychiatric side effects during peginterferon and ribavirin therapy for chronic hepatitis C. Aliment Pharmacol Ther. 2006;24(8):1223-1230.

98. Horikawa N, Yamazaki T, Izumi N, Uchihara M. Incidence and clinical course of major depression in patients with chronic hepatitis type $\mathrm{C}$ undergoing interferon-alpha therapy: a prospective study. Gen Hosp Psychiatry. 2003;25(1):34-38.

99. Hauser P, Khosla J, Aurora H, et al. A prospective study of the incidence and open-label treatment of interferon-induced major depressive disorder in patients with hepatitis C. Mol Psychiatry. 2002;7(9):942-947.

100. Miyaoka H, Otsubo T, Kamijima K, Ishii M, Onuki M, Mitamura K. Depression from interferon therapy in patients with hepatitis C. Am J Psychiatry. 1999;156(7):1120.

101. Martin-Santos R, Diez-Quevedo C, Castellvi P, et al. De novo depression and anxiety disorders and influence on adherence during peginterferon-alpha-2a and ribavirin treatment in patients with hepatitis C. Aliment Pharmacol Ther. 2008;27(3): $257-265$.
102. Gohier B, Goeb JL, Rannou-Dubas K, Fouchard I, Cales P, Garre JB. Hepatitis C, alpha interferon, anxiety and depression disorders: a prospective study of 71 patients. World J Biol Psychiatry. 2003;4(3):115-118.

103. Bonaccorso S, Marino V, Biondi M, Grimaldi F, Ippoliti F, Maes M. Depression induced by treatment with interferon-alpha in patients affected by hepatitis C virus. J Affect Disord. 2002;72(3): 237-241.

104. Lotrich FE, Rabinovitz M, Gironda P, Pollock BG. Depression following pegylated interferon-alpha: characteristics and vulnerability. J Psychosom Res. 2007;63(2):131-135.

105. Capuron L, Ravaud A, Miller AH, Dantzer R. Baseline mood and psychosocial characteristics of patients developing depressive symptoms during interleukin-2 and/or interferon-alpha cancer therapy. Brain Behav Immun. 2004;18(3):205-213.

106. Lindsay KL, Davis GL, Schiff ER, et al. Response to higher doses of interferon alfa- $2 \mathrm{~b}$ in patients with chronic hepatitis $\mathrm{C}$ : a randomized multicenter trial. Hepatitis Interventional Therapy Group. Hepatology. 1996;24(5):1034-1040.

107. Okanoue T, Sakamoto S, Itoh Y, et al. Side effects of high-dose interferon therapy for chronic hepatitis C. J Hepatol. 1996;25(3): 283-291.

108. Fried MW, Shiffman ML, Reddy KR, et al. Peginterferon alfa-2a plus ribavirin for chronic hepatitis $\mathrm{C}$ virus infection. $N$ Engl J Med. 2002;347(13):975-982.

109. Mulder RT, Ang M, Chapman B, Ross A, Stevens IF, Edgar C. Interferon treatment is not associated with a worsening of psychiatric symptoms in patients with hepatitis C. $J$ Gastroenterol Hepatol. 2002;15(3):300-303.

110. Renault PF, Hoofnagle JH, Park Y, et al. Psychiatric complications of long-term interferon alfa therapy. Arch Intern Med. 1987;147(9):1577-1580

111. Malaguarnera M, Di Fazio I, Restuccia S, Pistone G, Ferlito L, Rampello L. Interferon alpha-induced depression in chronic hepatitis $\mathrm{C}$ patients: comparison between different types of interferon alpha. Neuropsychobiology. 1998;37(2):93-97.

112. Iino S. High dose interferon treatment in chronic hepatitis C. Gut. 1993;34 Suppl 2:S114-S118

113. Kraus MR, Schafer A, Csef H, Scheurlen M. Psychiatric side effects of pegylated interferon alfa- $2 \mathrm{~b}$ as compared to conventional interferon alfa-2b in patients with chronic hepatitis C. World $J$ Gastroenterol. 2005;11(12):1769-1774.

114. Manns MP, McHutchison JG, Gordon SC, et al. Peginterferon alfa- $2 b$ plus ribavirin compared with interferon alfa- $2 b$ plus ribavirin for initial treatment of chronic hepatitis C: a randomised trial. Lancet. 2001;358(9286):958-965.

115. Zeuzem S, Feinman SV, Rasenack J, et al. Peginterferon alfa-2a in patients with chronic hepatitis C. N Engl J Med. 2000;343(23): 1666-1672.

116. Robaeys G, de Bie J, Wichers MC, et al. Early prediction of major depression in chronic hepatitis $\mathrm{C}$ patients during peg-interferon alpha-2b treatment by assessment of vegetative-depressive symptoms after four weeks. World J Gastroenterol. 2007;13(43): 5736-5740.

117. Quarantini LC, Bressan RA, Galvao A, Batista-Neves S, Parana R, Miranda-Scippa A. Incidence of psychiatric side effects during pegylated interferon- alpha retreatment in nonresponder hepatitis $\mathrm{C}$ virus-infected patients. Liver Int. 2007;27(8):1098-1102.

118. Amodio P, de Toni EN, Cavalletto L, et al. Mood, cognition and EEG changes during interferon alpha (alpha-IFN) treatment for chronic hepatitis C. J Affect Disord. 2005;84(1):93-98.

119. Bannink M, Fekkes D, van Gool AR, et al. Interferon-alpha influences tryptophan metabolism without inducing psychiatric side effects. Neuropsychobiology. 2007;55(3-4):225-231.

120. Donnelly S. Patient management strategies for interferon alfa- $2 b$ as adjuvant therapy of high-risk melanoma. Oncol Nurs Forum. 1998;25(5):921-927. 
121. Capuron L, Ravaud A. Prediction of the depressive effects of interferon alfa therapy by the patient's initial affective state. $N$ Engl J Med. 1999;340(17):1370.

122. Castellvi P, Navines R, Gutierrez F, et al. Pegylated interferon and ribavirin-induced depression in chronic hepatitis $\mathrm{C}$ : role of personality. J Clin Psychiatry. 2009;70(6):817-828.

123. Dell'Osso L, Pini S, Maggi L, et al. Subthreshold mania as predictor of depression during interferon treatment in $\mathrm{HCV}+$ patients without current or lifetime psychiatric disorders. J Psychosom Res. 2007;62(3):349-355.

124. Castera L, Zigante F, Bastie A, Buffet C, Dhumeaux D, Hardy P. Incidence of interferon alfa-induced depression in patients with chronic hepatitis C. Hepatology. 2002;35(4):978-979.

125. Dieperink E, Ho SB, Thuras P, Willenbring ML. A prospective study of neuropsychiatric symptoms associated with interferon-alpha-2b and ribavirin therapy for patients with chronic hepatitis C. Psychosomatics. 2003;44(2):104-112.

126. Ho SB, Nguyen H, Tetrick LL, Opitz GA, Basara ML, Dieperink E. Influence of psychiatric diagnoses on interferon-alpha treatment for chronic hepatitis $\mathrm{C}$ in a veteran population. Am J Gastroenterol. 2001;96(1):157-164.

127. Raison CL, Demetrashvili M, Capuron L, Miller AH. Neuropsychiatric adverse effects of interferon-alpha: recognition and management. CNS Drugs. 2005;19(2):105-123.

128. Dan AA, Martin LM, Crone C, et al. Depression, anemia and healthrelated quality of life in chronic hepatitis C. J Hepatol. 2006;44(3): 491-498.

129. Fontana RJ, Bieliauskas LA, Lindsay KL, et al. Cognitive function does not worsen during pegylated interferon and ribavirin retreatment of chronic hepatitis C. Hepatology. 2007;45(5):1154-1163.

130. Fontana RJ, Schwartz SM, Gebremariam A, Lok AS, Moyer CA. Emotional distress during interferon-alpha-2B and ribavirin treatment of chronic hepatitis C. Psychosomatics. 2002;43(5):378-385.

131. Hunt CM, Dominitz JA, Bute BP, Waters B, Blasi U, Williams DM. Effect of interferon-alpha treatment of chronic hepatitis $\mathrm{C}$ on healthrelated quality of life. Dig Dis Sci. 1997;42(12):2482-2486.
132. Kraus MR, Schafer A, Faller H, Csef H, Scheurlen M. Psychiatric symptoms in patients with chronic hepatitis $\mathrm{C}$ receiving interferon alfa-2b therapy. J Clin Psychiatry. 2003;64(6):708-714.

133. Maddock C, Baita A, Orru MG, et al. Psychopharmacological treatment of depression, anxiety, irritability and insomnia in patients receiving interferon-alpha: a prospective case series and a discussion of biological mechanisms. J Psychopharmacol. 2004;18(1):41-46.

134. Majer M, Welberg LA, Capuron L, Pagnoni G, Raison CL, Miller AH. IFN-alpha-induced motor slowing is associated with increased depression and fatigue in patients with chronic hepatitis C. Brain Behav Immun. 2008;22(6):870-880.

135. Schafer A, Wittchen HU, Seufert J, Kraus MR. Methodological approaches in the assessment of interferon-alfa-induced depression in patients with chronic hepatitis $\mathrm{C}$ - a critical review. Int J Methods Psychiatr Res. 2007;16(4):186-201.

136. Yovtcheva SP, Rifai MA, Moles JK, van der Linden BJ. Psychiatric comorbidity among hepatitis C-positive patients. Psychosomatics. 2001;42(5):411-415.

137. Yates WR, Gleason O. Hepatitis C and depression. Depress Anxiety. 1998;7(4):188-193.

138. Johnson ME, Fisher DG, Fenaughty A, Theno SA. Hepatitis C virus and depression in drug users. Am J Gastroenterol. 1998;93(5):785-789.

139. Kenis G, Prickaerts J, van Os J, et al. Depressive symptoms following interferon-alpha therapy: mediated by immune-induced reductions in brain-derived neurotrophic factor? Int J Neuropsychopharmacol. 2010 Jul 29;1-7. Epub 2010 Sep 1.

140. Capuron L, Raison CL, Musselman DL, Lawson DH, Nemeroff CB, Miller AH. Association of exaggerated HPA axis response to the initial injection of interferon-alpha with development of depression during interferon-alpha therapy. Am J Psychiatry. 2003;160(7):1342-1345.

141. Heinze S, Egberts F, Rotzer S, et al. Depressive mood changes and psychiatric symptoms during 12-month low-dose interferon-alpha treatment in patients with malignant melanoma: results from the multicenter DeCOG trial. J Immunother. 2010;33(1):106-114.

142. Sockalingam S, Abbey SE, Alosaimi F, Novak M. A review of sleep disturbance in hepatitis C. J Clin Gastroenterol. 2010;44(1):38-45.
Neuropsychiatric Disease and Treatment

\section{Publish your work in this journal}

Neuropsychiatric Disease and Treatment is an international, peerreviewed journal of clinical therapeutics and pharmacology focusing on concise rapid reporting of clinical or pre-clinical studies on a range of neuropsychiatric and neurological disorders. This journal is indexed on PubMed Central, the 'PsycINFO' database and CAS, and is the official

\section{Dovepress}

journal of The International Neuropsychiatric Association (INA). The manuscript management system is completely online and includes a very quick and fair peer-review system, which is all easy to use. Visit http://www.dovepress.com/testimonials.php to read real quotes from published authors. 